\title{
Changes in body weight, blood glucose and serum proteins in relation to the appearance of post-partum oestrus in Gir cows
}

\author{
J. S. Patil* and B. R. Deshpande \\ Veterinary College, Bombay, India
}

\begin{abstract}
Summary. Of 16 cows, 9 did not exhibit oestrus within 90 days of parturition. These 9 cows had significantly lower body weights, blood glucose and serum protein concentrations than did the 7 cows which exhibited a fertile oestrus. It is suggested that these differences could be used to identify those cows which will not show an early post-partum oestrus.
\end{abstract}

\section{Introduction}

In developed and developing countries it is economically important for cattle to conceive early after parturition, but the reasons for the delay in appearance of the post-partum oestrus are not understood. The present study was an examination of the differences between cows which did or did not exhibit oestrus within 90 days after parturition.

\section{Materials and Methods}

A total of $16 \mathrm{Gir}$ cows in late pregnancy was selected for study: of these 3, 2, 2, 3, 1, 3, 1 and 1 had experienced $1,2,3,4,5,6,7$ and 8 lactations respectively. All the cows were lactating and suckling a calf during the study period. The animals were stationed at the Cattle Breeding Farm, Kandivli, situated $35 \mathrm{~km}$ north of Bombay, at $18^{\circ} \mathrm{N}$ and $72^{\circ} \mathrm{E}$ in the western coastal strip of India where there is heavy rainfall and high humidity. The animals were stall-fed, and had unrestricted access to hay and $2 \mathrm{~kg}$ concentrate feed of the following formula was fed per animal: $40 \%$ wheat bran, $30 \%$ ground nut cake, 15\% Gowar chuni and $15 \%$ Tur chuni. Half of the concentrate was mixed with an equal amount of Hindlever special milk ration in which the crude protein percentage was $20 \%$. Body weights were recorded on the day of parturition and every 15 days (a.m.) after parturition until 90 days. Blood samples were also taken on the day of parturition and every 15 days thereafter by jugular venepuncture, kept at $10^{\circ} \mathrm{C}$ for $24 \mathrm{~h}$ and centrifuged to remove serum which was assayed immediately. Total serum protein and blood glucose were estimated by the methods of Lowry, Rosebrough, Farr \& Randall (1951) and Folin \& Wu (1920) respectively. Each serum sample was estimated in duplicate or triplicate to give an average value. During the 90-day period of study the occurrence of oestrus was detected by observation of behaviour with a vasectomized teaser bull, twice daily examination of the cows and weekly examination of the ovaries by rectal palpation. Any cows exhibiting oestrus were artificially inseminated and were confirmed pregnant at rectal examination after 45-60 days.

\footnotetext{
* Present address: Department of Animal Breeding, College of Animal Sciences, Haryana Agricultural University,
} Hissar 125004, India. 


\section{Results}

The changes in body weight after parturition are shown in Table 1 and those in blood glucose and serum proteins are illustrated in Text-fig. 1. There was clearly a difference in these changes in the cows which did exhibit oestrus and in those which did not. The 7 cows which showed oestrus did so at $60-65$ days and all conceived.

Table 1. Body weight changes $(\mathrm{kg})$ in cows after parturition

\begin{tabular}{lccccccc}
\hline \multicolumn{7}{c}{ Time after parturition (weeks) } \\
\cline { 2 - 8 } & 0 & 2 & 4 & 6 & 8 & 10 & 12 \\
\hline Cows exhibiting & 371.43 & 361.85 & 365.57 & 370.04 & 376.28 & 381.00 & 384.57 \\
oestrus (N=7) & \pm 9.35 & \pm 9.58 & \pm 9.64 & \pm 9.34 & \pm 9.40 & \pm 9.41 & \pm 9.24 \\
Cows not & 351.77 & 346.66 & 344.44 & 341.66 & 337.77 & 334.44 & $331.77^{*}$ \\
$\quad$ exhibiting & \pm 9.35 & \pm 9.48 & \pm 9.52 & \pm 9.44 & \pm 9.20 & \pm 9.07 & \pm 9.03 \\
oestrus (N=9) & & & & & & & \\
\hline
\end{tabular}

Values are mean \pm s.e.m. for the no. of cows in parentheses.

* Significantly different from value for cows exhibiting oestrus.
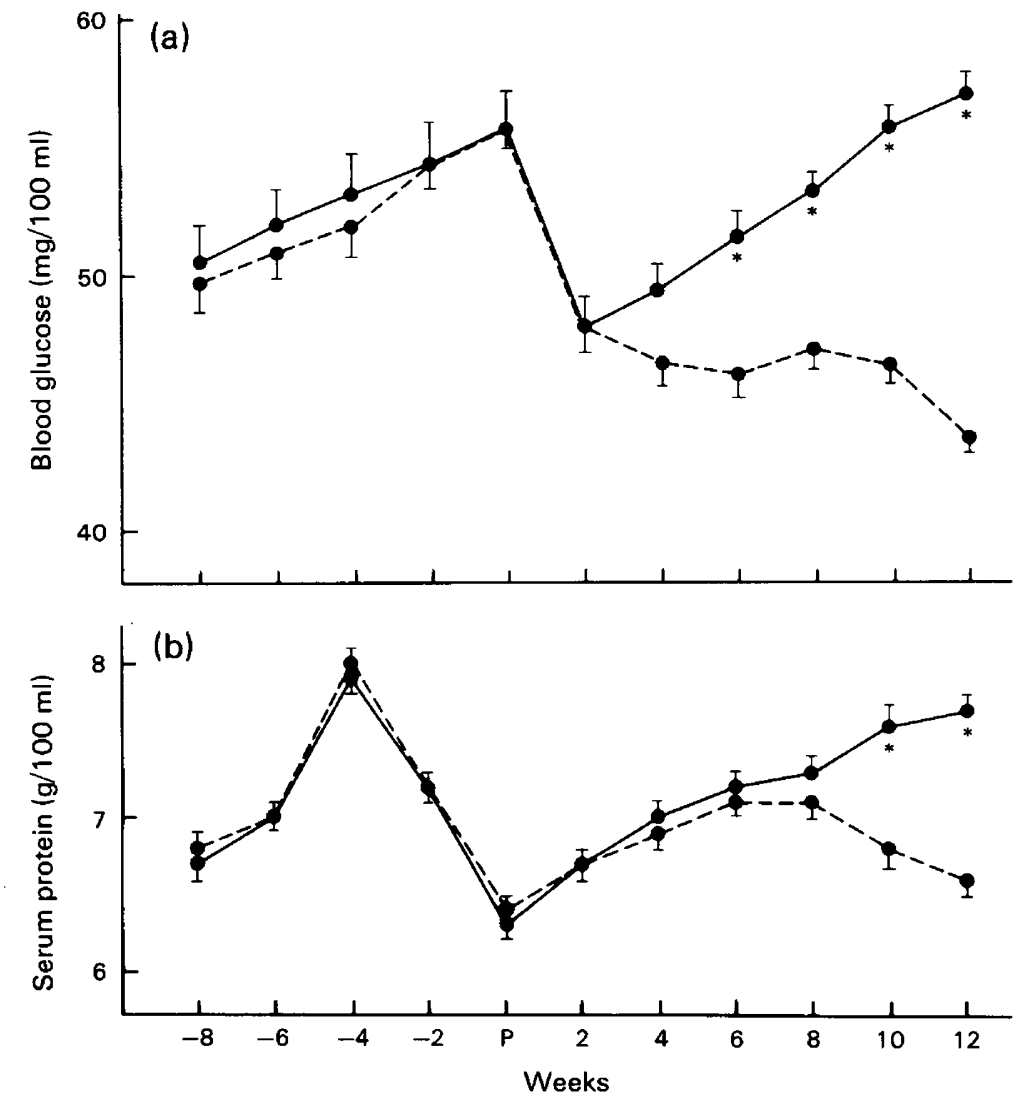

Text-fig. 1. Changes (mean \pm s.e.m.) in (a) blood glucose concentrations and (b) serum protein concentrations in cows which did $(-)$ or did not $(--)$ exhibit oestrus within 90 days of parturition (P). Asterisks indicate values which are significantly different $(P<0.05)$. 


\section{Discussion}

The present observations on body weight loss and anoestrus in cows agree with those of McClure (1965, 1970), Baker (1969), King (1968), Rangiah (1971) and Mokashi (1972) who observed that reduced body weight after parturition was associated with low fertility, and animals which gained in body weight after parturition exhibited early oestrus. The values for blood glucose recorded in the present study are in close agreement with those reported by Horrocks \& Paterson (1957, 1960) and Anon (1973-74): the decreasing values in those cows which did not exhibit oestrus and gradual increases in those cows which showed oestrus within 90 days are similar to the observations reported by Hewitt (1930), Mokashi (1972) and Anon (1974-75).

The serum protein levels recorded were in close agreement with the values reported by Larson \& Kendall (1957), Humana \& Usui (1973) and Anon (1973-74). Values remained steady after parturition in cows which did not show oestrus within 90 days but increased significantly in those which did. This observation may be related to lactation history since in the present study 7 of the 9 cows failing to express oestrus within 90 days of parturition had had at least 4 lactations.

Consideration of any one of the three characteristics studied, body weight, blood glucose or serum protein, could be used to predict which cows are going to show an early post-partum oestrus.

We are grateful to Dr C. R. Sane, Veterinary Advisor, Gow-Rakshak Mandali, Bombay and to Dr M. R. Bhosrekar (BAIF) for their constructive suggestions. The work is part of a thesis submitted for the M.V.Sc. to Konkan Krishi Vidyapeeth, Dapoli.

\section{References}

Anon (1973-74) Milk Marketing Board, Report of the Breeding and Production Organisation, No. 24, pp. $60-62$.

Anon (1974-75) Milk Marketing Board, Report of the Breeding and Production Organisation, No. 25, pp. 85-86.

Baker, A.A. (1969) Post partum anoestrus in cattle. Aust. vet. J. 45, 180-182.

Folin, O. \& Wu, H. (1920) A simplified and improved method for determination of sugar. J. biol. Chem. 41, 367-374.

Hewitt, E. A. (1930) Blood sugar level of the bovine. $J$. Am. vet. med. Ass. 77, 362-367.

Horrocks, D. \& Paterson, J.Y.F. (1957) Some observations on glucose ketone bodies and volatile fatty acids in the blood of dairy cattle. J. comp. Path. 67, 331-341.

Horrocks, D. \& Paterson, J.Y.F. (1960) Further observations on blood components in lactating dairy cattle. J. comp. Path. 70, 109-114.

Humana, K. \& Usui, K. (1973) Change in serum protein and plasma level associated with pregnancy and parturition in the bovine and the rabbit. Vet. Bull. 43, 4289.
King, J.O.L. (1968) The relation between conception rate and change in the body weight, yield and SNF content of milk in dairy cows. Vet. Res. 83, 492-494.

Larson, B.L. \& Kendall, K.A. (1957) Changes in specific blood serum protein level associated with parturition in the bovine. J. Dairy Sci. 40, 659-663.

Lowry, O.H., Rosebrough, N.J., Farr, A.L. \& Randall, R.J. (1951) Protein measurement with the folin phenol reagent. J. biol. Chem. 193, 265-275.

McClure, T.J. (1965) Experimental evidence for the occurrence of nutritional infertility in otherwise clinically healthy pasture fed lactating dairy cows. Res. vet. Sci. 6, 202-205.

MeClure, T.J. (1970) A review of development in nutrition as it is related to the fertility in cattle. N.Z. vet. J. 18, 61-68.

Mokashi, B.G. (1972) Study on past-partum anoestrus condition and effectiveness thereon at the increased energy intake. M.V.Sc. thesis, M.P.K.V. Rahuri.

Rangiah, K. (1971) Observation and evaluation of uterus and post-partum fertility in a group of Gir cows with special reference to nutritional status. M.V.Sc. thesis, M.P.K.V. Rahuri. 